Original Contribution

\title{
STUDY ON THE EFFECTIVENESS OF INTRACISTERNAL ANTIBIOTIC TREATMENT FOR THE CONTROL OF MASTITIS IN GOATS
}

\author{
K. Hristov ${ }^{1}$, R. Pepovich ${ }^{1}$, B. Nikolov ${ }^{2}$, G. Stoimenov ${ }^{1}$ \\ ${ }^{1}$ Faculty of Veterinary Medicine, University of Forestry, Sofia, Bulgaria \\ ${ }^{2}$ Private Veterinary Clinic "Vet Serviz", Pleven, Bulgaria
}

\begin{abstract}
The aim of this study is to investigate the healing and prophylactic effect of drying-off antibiotic therapy using the selective and non-selective approach of administration of the antibiotics. First experimental group at the start of the dry period were treated non-selectively (all halves) intracisternally with antibiotics. In the second group, we only treated those halves that were diagnosed with subclinical mastitis. The control group of 9 goats was not treated.

The number of somatic cells in treated groups after birth decreased from $2586 \times 10^{3} / \mathrm{mL}$ to $560 \mathrm{x}$ $10^{3} / \mathrm{mL}$ in the first group and from $1978 \times 10^{3} / \mathrm{mL}$ to $526 \times 10^{3} / \mathrm{mL}$ in the second. Post partum, $10 \%$ of the halves were found to have subclinical mastitis. A healing effect was achieved in $25 \%(\mathrm{n}=5) \mathrm{milk}$ halves. New intramammary infections developed during the dry period also occurred in $5 \%(n=1)$ of the milk halves. In the second post-partum study, subclinical mastitis was observed only in $5 \%(\mathrm{n}=1)$. Healing was achieved in $30 \%(\mathrm{n}=6)$ and the new intramammary infections (NIMIs) were $10 \%(\mathrm{n}=2)$. In the control group, healing was only observed in 5\% $(n=1)$ and NIMI were $27.78 \%(n=5)$.

The application of both treatment approaches, results in reduction in prevalence and manifestation of mastitis, as well as reduction of somatic cells in milk after kidding. The selective treatment method may be preferred, in order to reduce the cost of medications in conducting treatment and prophylaxis programs.
\end{abstract}

Key words: dry period, goats, mastitis, prophylaxis

\section{INTRODUCTION}

Numerous factors such as breeding systems, breed, age, lactation, oestrus and intramammary infections (IMI) affect the number of somatic cells (SCC) in goat milk (1$3)$. Since the total number of SCC is indicative of the number of neutrophils and in turn they are the main symptom of infection, SCC is used as a marker for mastitis. Several authors (4-6) reported differences in milk SCC between uninfected and infected udder halves in goats.

Possibilities for control and prophylaxis of mastitis include genetic selection, nutrition, stress reduction, and good hygiene in stocking and milking. Feeding plays an important role in mammary gland resistance, because trace elements such as various antioxidants, vitamin

\footnotetext{
*Correspondence to: KALIN HRISTOV,

University of Forestry, Faculty Veterinary

Medicine, 10 Kliment Ohridsky Blvd., Sofia 1797,

Bulgaria, e-mail: khristov@ltu.bg, +359883336939
}

A, $\beta$-carotene, zinc and chromium affect the lactation protection mechanisms, including leukocyte function and deficiency of these trace elements, is associated with an increase in incidence, duration and severity of mammary diseases. Prophylaxis of subclinical mastitis involves a number of procedures: milking hygiene, disinfection post milking, dry-period treatment, and timely diagnosis of new cases $(7,8)$. In addition, different routes and regimens of antimicrobials usage are important (9).

The aim of our study was to investigate the curative and prophylactic effect of drying-off antibiotic therapy using selective and nonselective application of the formulations.

\section{MATERIALS AND METHODS Animals}

This study was performed in goat farms located in the territory of 4 districts of Bulgaria. In order to investigate the possibility of prophylaxis of dry period mastitis and the 
rehabilitation of the existing cases during the period, we used 29 goats with a total of 58 milk halves. The herd consisted mainly of Bulgarian white dairy goat (BWDG) and local crosses. The animals included in the experimental groups were equalized by age -4 years. The system of cultivation is semiintensive, where, after the end of the grazing period, the animals are provided with roughage and concentrated feed during the winter months, during which they are housed indoors.

\section{Experimental groups}

In 1 group, were included 10 animals which, at the start of the dry period were treated nonselectively (all halves) intra-cisternally with Cloxacillin (as Cloxacillin Benzathine). In the second group of 10 goats, we undertook a selective approach in treatment (we only treated those halves that were diagnosed with subclinical mastitis). The control group of 9 goats was not treated.

\section{Determining the status of the mammary gland}

The studies to determine the mastitis status of all the animals were performed two weeks before the draining and two weeks after kidding. The number of cellular elements was determined by indirect tests CMT-Test (Kruuse, Denmark) and Porta SCC (Porta Check, USA). Interpretation of CMT results was performed according to the proposed by Smith and Sherman (2009) (10) scale, and those of the Porta SCC test according to the kit, provided by the manufacturer. The direct counting was carried out using method BDS EN ISO 13366-2 / IDF 148-2: 2006 through Fossomatic (Foss, Denmark).
The microbiological study was carried out according to the accepted methodology for isolating and differentiating the causative agents. Milk samples were plated in elective and selective nutrient media for bacteria of different groups, as well as fungi. They were cultivated at $37^{\circ} \mathrm{C}$ and $28^{\circ} \mathrm{C}$ for $24-72$ hours under aerobic conditions. The following nutrient media were used: blood agar, folate azide isolation medium for Enterococcus spp. (BIO BIO - NCIPD LTD - Sofia), agar and broth of Mueller Hinton, Eosin Methylene Blue agar for Gram-negative aerobic and facultative anaerobic bacteria, Cetrimide agar for isolating species of Pseudomonas genus; Chapman Stone agar for Staphylococci and Sabouro agar for dermatophytes (Antisel Sharlau Chemie S.A., Spain). Taxonomic identification of isolated bacteria was performed by microscopic examination of Gram and Pfiffer stained slides, taking into account the cultural features and the biochemical properties with the help of Polymicrotest (NCIPD - Sofia) and additional samples for oxidase, catalase and others with reagents from Antisel - Sharlau Chemie S.A., Spain.

\section{Statistical analysis}

The statistical analysis was performed using ANOVA and T-test of SPSS 16.0

\section{RESULTS}

The results of microbiological studies have been published in our previous publications (11). The effect of antibiotic intra-cisternal treatment of animals on somatic cell counts at drying-off is shown in Table 1.

Table 1. Influence of treatment at drying-off on somatic cell counts (SCC) from goat milk samples

\begin{tabular}{|c|c|c|}
\hline Experimental group & $\begin{array}{c}\text { Means of SCC } \mathbf{~ 1 0} \mathbf{3} / \mathbf{m L} \\
\text { before dry period } \\
\text { (udder half with SCM) }\end{array}$ & $\begin{array}{c}\text { Means of SCC } \mathbf{~ 1 0} \mathbf{3} / \mathbf{m L} \\
\text { after kidding } \\
\text { (the same udder half) }\end{array}$ \\
\hline I & 2586 & $560^{*}$ \\
\hline II & 1978 & $526^{*}$ \\
\hline control & 2156 & 1960 \\
\hline
\end{tabular}

The number of somatic cells in treated groups after birth decreased respectively from $2586 \mathrm{x}$ $10^{3} / \mathrm{mL}$ to $560 \times 10^{3} / \mathrm{mL}$ in the first test group and from $1978 \times 10^{3} / \mathrm{mL}$ to $526 \times 10^{3} / \mathrm{mL}$ respectively in the second.
Table 2 shows the results of the curative and prophylactic effect after intramammary treatment by the two different approaches before drying off. 
HRISTOV K. et al.

Table 2. Results of the prophylactic effect of antibiotic intramammary treatment in goats with subclinical mastitis

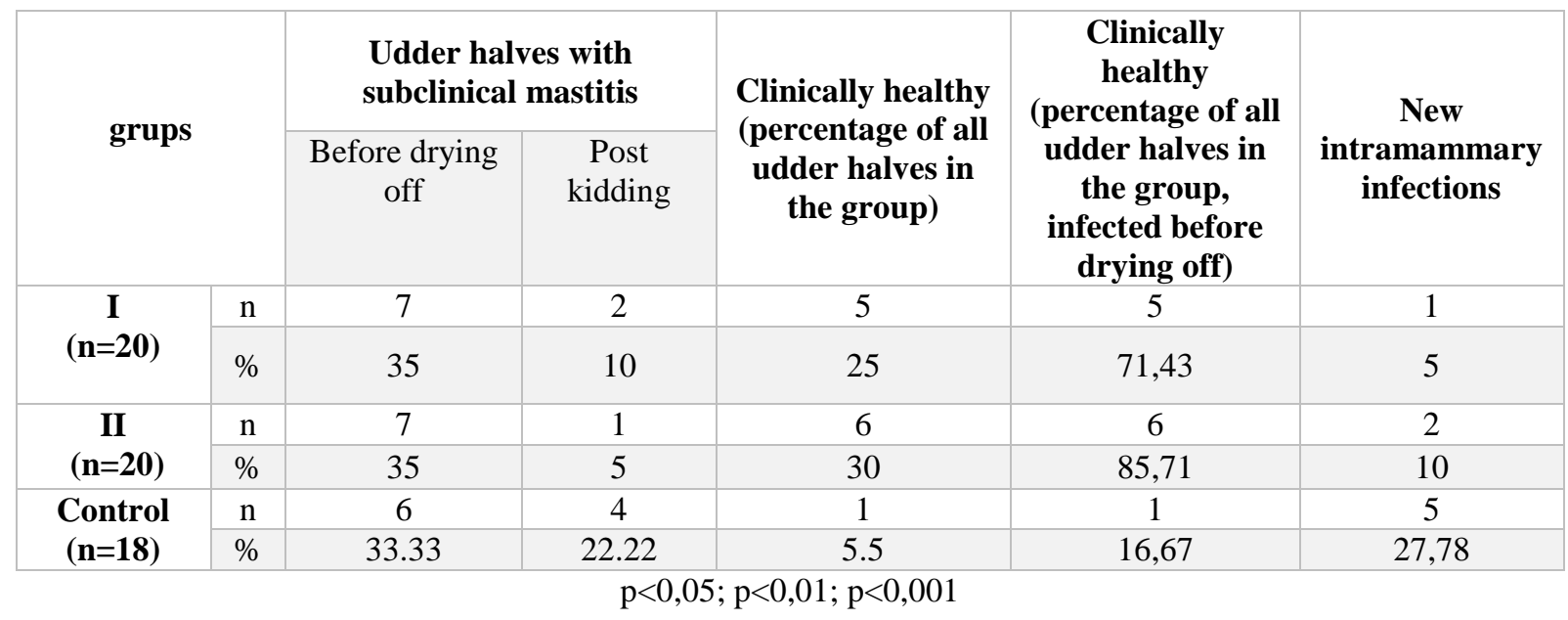

In the first experimental group consisting of 10 animals (20 milk halves), 35\% ( $\mathrm{n}=7)$ at the time of drying had subclinical mastitis. After kidding, $10 \%$ of the halves were found to have subclinical mastitis. The clinical healing effect was achieved in 5 milk halves $(25 \%)$ with a confidence level $\mathrm{p}<0.05$. New intramammary infections developed during the dry period occurred in $5 \%(\mathrm{n}=1)$ of the udder halves $(\mathrm{p}$ $<0.05)$.

In the second experimental group, at the time of drying, subclinical mastitis was again $35 \%$ $(n=7)$ of all cases, but post partum, subclinical mastitis was observed only in $5 \% \quad(n=1)$. Healing was achieved in $30 \%(n=6)$ at $p<0.01$ and the new intramammary infections (NIMIs) were $10 \%(n=2)$ with $p<0.05$. The control group had only $5 \% \quad(\mathrm{n}=1)$ spontaneous recovery rate and NIMI were $27.78 \%(n=5)$.

\section{DISCUSSIONS}

The number of somatic cells in milk is the main health indicators of the mammary gland. With the development of subclinical mastitis occur changes in the composition and physicochemical parameters of milk. Dry-off antibiotic and dry-off antibiotic with teat sealant therapy reduced milk SCC levels (12)

In our study somatic cell counts in treated milk halves significantly decreased after birth, confirming the curative and prophylactic effect of intracisternal antibiotic therapy. At the same time, a similar decrease in somatic cells was observed in the control group of untreated udder halves, albeit significantly less. The reduction of SCC in the milk after kidding in the treated goats and the clearance of a large proportion of the affected halves confirmed that infectious status had a major impact on SCC content. (7)
SCC in milk was significantly lower after kidding for goats treated at drying-off. However, after 75 days of lactation, the geometric means of SCC in milk were similar for treated and control groups.

In most studies, primary consideration is given to the curative rather than the prophylactic effect of antibiotic treatment. In this regard, the results after antibiotic use are expressed as a relative share in percent of the halves affected by subclinical mastitis, whereas in our experimental groups, we included healthy milk halves to determine the rate of new intramammary infections and the potential protective effect of intracisternal treatment. The difference in the number of new intramammary infections between the two test groups and the control (I-1, II-2 and control-5) is a clear evidence of the protective effect of topically applied antibiotics regardless of the treatment approach.

Some authors suggests that over $50 \%$ of new infections may occur in the next lactation if they are not adequately treated at the same time new infections occurring during the dry period may cause clinical mastitis during the next lactation (13).

Analysis of the data in terms of the total number of halves included in the respective test groups shows, although less pronounced, the difference between the two treatment methods with regard to the prophylactic effect. The treatment effect in the first trial group was $71.48 \%$ and in the second group $85.71 \%$. At the same time, spontaneously recovered untreated halves expressed in the same way are only $16.67 \%$. Bogolin and Vasiu, (2008) (14) reported $70.21 \%$ efficacy after treatment with the same preparation, and spontaneous healing 
in untreated halves with subclinical mastitis was $19.15 \%$.Similar results with a cure rate of $78.9 \%$ were reported by Fox et al. (1992) (15) after selective intramammary therapy by cepharin benzathine preparation labeled for cows in 49 does with IMI predominantly caused by coagulase-negative Staphylococci.

Anniss and McDougall (2002) (16) reported the positive effect of mammary gland antibiotic treatment during the dry period, the effect being recovery of a large part of the subclinical mastitis halves and the appearance of a small percentage of new infections.

\section{CONCLUSION}

From a clinical point of view, both approaches to the control of subclinical mastitis in goats would reduce and limit the spread and reduce somatic cells counts after kidding. However, due to the insignificant differences in newly emerging intramammary infections in the selective treatment method, this method may be preferred in order to reduce the cost of medication in conducting treatment and prophylactic programs.

\section{ACKNOWLEDGEMENTS}

The present study was initiated and implemented with the support of the National Science Program "Young Scientists and Postdoctoral Students". We express our gratitude for the concern for the young researchers, scientists and professors in Bulgaria.

\section{REFERENCES}

1. McDougall, S. and Voermans, M., Influence of estrus on somatic cell count in dairy goats. J. Dairy Sci, 85:378-383, 2002.

2. Moroni P., Pisoni, G., Savoini G., Van Lier E., Acuna, S., Damian J. P. and Meikle A., Influence of estrus of dairy goats on somatic cell count, milktraits, and sex steroid receptors in the mammary gland. $J$. Dairy Sci, 90:790-797, 2007.

3. Bartha K., Aulricha K., Muller U. and Knappstein K., Somatic cell count, lactoferrin and NAGase activity in milk of infected and non-infected udder halves of dairy goats. Small Ruminant Research, 94:161-166, 2010.

4. Luengo C., Sa'nchez A., Corrales J. C., Ferna'ndez C. and Contreras A., Influence of intramammary infection and noninfection factors on somatic cell counts in dairy goats. Journal of Dairy Research, 71:169-174, 2004.
HRISTOV K. et al.

5. Boulaaba A., Grabowski N. and Klein G., Differential cell count of caprine milk by flow cytometry and microscopy. Small Ruminant Research, 97:117-123, 2011.

6. Persson, Y. and Olofsson, I., Direct and indirect measurement of somatic cell count as indicator of intramammary infection in dairy goats. Acta Vet Scand 53:15. 2011, https://doi.org/10.1186/1751-0147-53-15

7. Poutrel B., DeCremoux, R., Ducelliez M. And Verneau D., Control of intramammary infections in goats: impact on somatic cell counts, Journal of Animal Science, 75(2):566-570, 1997.

8. Menzies, P. I. and Ramanoon, S. Z., Mastitis of sheep and goats. Vet. Clin. North. Am. Food Anim. Pract, 17: 333-358, 2001.

9. Doğgruer G., Saribay, M., Ergun Y., Aslantaş O., Demir C. and Ateş C., Treatment of subclinical mastitis in Damascus goats during lactation. Small Ruminant Research, 90 153-155, 2010.

10.Smith, M. C. and Sherman D. M. Goat Medicine, Second Edition, WileyBlackwell. 2009.

11.Hristov, K., Popova, T., Pepovich R. and Nikolov, B., Characterization of Microbial Causative Agents of Subclinical Mastitis in Goats in Bulgaria, Int.J.Curr. Microbiol.App.Sci. 5 (8): 316-323, 2016.

12.Baştan, A., Salar, S., Bakiacar, D., Demirel, M., Cengiz, M., Darbaz, İ. and Bulut, G., The effects of dry-off therapy on milk somatic cell count in Saanen goats, Turk J Vet Anim Sci, 39: 550-555, 2015

13.Berry E. A. and Hillerton J.E., The effect of an intramammary teat seal on new intramammary infections. J Dairy Sci, 85: 2512-2520, 2002

14.Bogolin I. and Vasiu C., Treatment of subclinical intramammary infections in small ruminants. Buletin USAMV Veterinary Medicine, 65(2):298-303, 2008.

15.Fox L.K., Hancock D. D. and Horner S. D., Selective intramammary antibiotic therapy during the nonlactating period in goats. Small Rumin. Res, 9(3):313-318, 1992.

16. Anniss F. M. and McDougall S., Efficacy of antibiotic treatment at drying off in curing existing infections and preventing new infections in dairy goats. Proceedings of the 62-nd Conference of the NewZealand Society of Animal Production,. 2426 June, (pp. 19-21), Massey University, New Zealand, 2002. 